\title{
Assessment of Rumen Microbial Adaptation to Garlic Oil, Carvacrol and Thymol Using the Consecutive Batch Culture System
}

\author{
Mbiriri DT ${ }^{1}$, Cho $\mathrm{S}^{2}$, Mamvura $\mathrm{CI}^{1}$ and Choi $\mathrm{NJ}^{* 1}$ \\ ${ }^{1}$ Department of Animal Science, Chonbuk National University, Jeonju, Republic of Korea \\ ${ }^{2}$ Institute of Circulation Agriculture and Livestock Solutions, CALS Co., Ltd., Gyeonggi, Republic of Korea
}

*Corresponding author: Choi NJ, Department of Animal Science, Chonbuk National University, Jeonju, Republic of Korea 561-756, Email: nagjin@jbnu.ac.kr

Citation: Mbiriri DT, Cho S, Mamvura CI, Choi NJ (2016) Assessment of Rumen Microbial Adaptation to Garlic Oil, Carvacrol and Thymol Using the Consecutive Batch Culture System. J Vet Sci Anim Husb 4(1): 101. doi: 10.15744/2348-9790.4.101

Received Date: August 02, 2015 Accepted Date: January 13, 2016 Published Date: January 15, 2016

\begin{abstract}
Although plant derivatives have shown promise in reducing enteric methane $\left(\mathrm{CH}_{4}\right)$ emissions from ruminants in short-term studies, investigation on possible rumen microbial adaptation to these compounds is still limited. The objective of this study was to assess the possibility of mixed rumen microbial adaptation to antimethanogenic plant derivatives over relatively long-term in vitro incubation. Treatments were: garlic oil, carvacrol and thymol, each at a final concentration of $300 \mathrm{mg} / \mathrm{l}$. A control, containing no additive, was included. The fermentations were done using the consecutive batch culture system with two serial subculture transfers at three-day intervals. The substrate was a mixture of forage and concentrate in a ratio of 60:40. Incubations were conducted in triplicate with rumen fermentation parameters being determined at days 3, 6 and 9. Indications of rumen microbial adaptation were observed in carvacrol and thymol as $\mathrm{CH}_{4}$ significantly increased from almost complete inhibition at day 3 to almost $5 \%$ of total gas at day 9. This was closely associated with a rise in methanogenic archaea populations from being significantly lower $(\mathrm{p}=0.0026)$ at day 3 to being numerically higher $(\mathrm{p}=0.0632)$ than the control by day 9 . Garlic oil consistently suppressed $(\mathrm{p}<0.0001) \mathrm{CH}_{4}$. Carvacrol and thymol suppressed overall fermentation, resulting in lower $(\mathrm{p}<0.0001)$ VFA concentrations and hence higher culture $\mathrm{pH}(\mathrm{p}<0.0001)$. Garlic oil did not differ from the control on VFA concentrations $(p>0.05)$ except for butyrate $(p=0.04)$. Treatments had no overall effect on total bacteria $(\mathrm{p}=0.235)$ and protozoa numbers $(\mathrm{p}=0.835)$. The effects of carvacrol and thymol on fermentation parameters suggested that these supplements lower $\mathrm{CH}_{4}$ indirectly by suppressing overall fermentation whereas garlic oil selectively inhibits methanogens directly. We concluded that rumen microbes adapted to carvacrol and thymol. These supplements need to be tested in vivo to see if similar effects will be observed.
\end{abstract}

Keywords: Consecutive batch culture; Essential oils; Methane; Microbial adaptation; Rumen fermentation

Abbreviations: A/P: Acetate : Propionate; $\mathrm{CH}_{4}$ : Methane; DM: Dry matter; DNA: Deoxyribonucleic acid; $\mathrm{H}_{2}$ : Hydrogen; N: Nitrogen; PCR: Polymerase chain reaction; qRT-PCR: Quantitative real-time polymerase chain reaction; rRNA: Ribosomal ribonucleic acid; VFA: Volatile fatty acid

\section{Introduction}

Livestock production, particularly ruminant production, contributes significant amounts of methane $\left(\mathrm{CH}_{4}\right)$, a greenhouse gas with a global warming potential at least 20 times that of carbon dioxide [1], into the atmosphere. $\mathrm{CH}_{4}$ originating directly from ruminants is a byproduct of carbohydrate fermentation. Ninety percent of enteric $\mathrm{CH}_{4}$ from ruminant animals comes from the fore stomach and $10 \%$ comes from hindgut fermentation [2]. Recent efforts to reduce $\mathrm{CH}_{4}$ emissions from ruminants have focused on natural products, primarily of plant origin. Although plant-based products have generated a lot of attention, relatively fewer long-term studies on their effects have been conducted to date. Most in vitro studies on the effects of essential oils and other plant products have been short-term incubations, lasting $24 \mathrm{~h}$ to $48 \mathrm{~h}$ [3-5]. This poses a challenge considering that rumen microbial adaptation to these plant-based products remains a possibility over longer periods of exposure [6,7].

Carvacrol and thymol are related phenolic compounds found in essential oils of thyme and oreganum [8]. These compounds have long been established as antibacterial and antifungal. They have been shown to affect a wide range of Gram-positive and Gramnegative bacteria [9]. Although they reduce $\mathrm{CH}_{4}$ production in vitro, their incorporation also reduces volatile fatty acid (VFA) concentration, hence would be deleterious to animals if these effects are sustained in vivo [3]. Suppressed VFA concentrations are a result of overall fermentation being negatively affected. However, Busquet et al. [7], after applying carvacrol at a low dose (2.2 $\mathrm{mg} / \mathrm{l}$ ) in a continuous culture system suggested that rumen microbes could adapt to carvacrol. Studies in food preservation have also shown that pathogenic bacteria ordinarily inhibited by carvacrol or thymol can adapt to non-lethal concentrations of these phenolic compounds $[8,10]$. 
Garlic oil, a derivative of garlic, has been effective in suppressing ruminal $\mathrm{CH}_{4}$ and maintaining VFA concentration in most in vitro studies [11]. This essential oil directly inhibits methanogens [4]. Although the application of garlic oil in vivo has so far been limited, the few studies that have been conducted have not shown effective reduction in $\mathrm{CH}_{4}$ emissions and this has been attributed to possible microbial adaptation [6] or the lower concentrations applied compared to concentrations in vitro [12].

Researches that specifically studied the effects of plant extracts on rumen archaea or their possible adaptation are limited [13]. The objective of this study was to determine whether archaea and other rumen microbes adapt to garlic oil, carvacrol or thymol when added at a dosage that suppresses methanogenesis in a relatively long-term in vitro incubation. We monitored rumen microbial populations using the quantitative real-time polymerase chain reaction (qRT-PCR) technique.

\section{Materials and Methods}

\section{Experimental treatments and design}

Experimental treatments were; garlic oil (artificial), carvacrol (98\% purity) and thymol (98\% purity) at a final concentration of $300 \mathrm{mg} / \mathrm{l}$ and a control (no additive). Garlic oil, carvacrol and thymol were dissolved in absolute ethanol to make stock solutions. Stock solutions of treatments were prepared so that $50 \mu \mathrm{l}$ of the stock would result in a final concentration of $300 \mathrm{mg} / \mathrm{l}$ for each compound when added to $40 \mathrm{ml}$ of buffered rumen fluid. In the control was added $50 \mu \mathrm{l}$ of ethanol. Garlic oil and carvacrol were sourced from Sigma-Aldrich Company (Sigma-Aldrich, St. Louis, MO, USA) and thymol from Dae Jung Chemicals and Metals Co., LTD (Dae Jung, Siheung, Korea).

\section{Rumen inoculum and consecutive batch culture incubation}

Incubations followed the consecutive batch culture system, a method developed in the 1980s [14]. It is an in vitro system that allows maintaining of actively fermenting mixed populations of rumen bacteria over a long period of time. Subcultures from a previous fermentation are added into fresh buffer and incubated at the desired temperature. The process is repeated after every defined interval for as long as is necessary. In the present study we did three serial transfers at a three-day interval in $120 \mathrm{ml}$ serum bottles as outlined in a study by Morgavi et al. [15]. Rumen inoculum was obtained from two rumen-cannulated Hanwoo (Korean native beef breed) steers. The fluid was mixed with McDougall's buffer [16] at a ratio of 1:4. Ten milliliters of the mixed rumen fluid were dispensed into serum bottles containing $30 \mathrm{ml}$ of McDougall's buffer solution and $0.5 \mathrm{~g}$ of substrate. The substrate was made up of orchard grass and a commercial concentrate at a ratio of 60:40. The dry matter content of orchard grass and the commercial concentrate used in this study were $92.92 \%$ and $95.46 \%$ respectively. Organic matter, crude protein, ether extract and crude fiber content in orchard grass were 92.71, 7.77, 1.70 and 31.21\% DM whereas in the commercial concentrate they were 93.30, 13.88, 4.23 and $10.76 \%$ DM respectively.

\section{Parameter determination and chemical analyses}

At the end of each incubation period total gas production was measured by way of displacing a glass syringe. The collected gas was stored in aluminum vacutainers for further analysis of $\mathrm{CH}_{4}$ and $\mathrm{H}_{2}$. The analyses of these gases were carried out using a gas chromatograph (GC-7890A, Agilent Technologies, Inc. Santa Clara, CA, USA) fitted with a thermal conductivity detector and a capillary column ( Nukol $^{\mathrm{Tm}}$ Fused silica capillary column $30 \mathrm{~m} \times 0.25 \mathrm{~mm} \times 0.25 \mu \mathrm{m}$ film thickness, Supelco, Bellefonte, USA) according to procedures outlined by Lopez et al. [17].

Soon after determining total gas production, a $10 \mathrm{ml}$ subculture was transferred, under anaerobic conditions, into $30 \mathrm{ml} \mathrm{McDougall}$ 's buffer containing respective treatments. The remaining contents were transferred into $50 \mathrm{ml}$ conical tubes and $\mathrm{pH}$ determined using a pH meter (Mett-Toledo AG, Schwerzenbach, Switzerland). The fermentation fluid was then centrifuged at 3,100 $\times g$ for 20 min at $4{ }^{\circ} \mathrm{C}$ and $1.5 \mathrm{ml}$ samples of the supernatant stored at $-20{ }^{\circ} \mathrm{C}$ for VFA and ammonia nitrogen (N) analyses. Before analyzing for VFAs, $1 \mathrm{ml}$ of each sample was pretreated with $0.2 \mathrm{ml}$ of $25 \%$ metaphosphoric acid, allowed to settle for 30 min before centrifuging at 12,300 $\times g$ using a table-top centrifuge (Gyrozen mini, Seoul, Korea), then transferred into vials for analysis. VFA were analyzed using a gas chromatograph (GC-7890A, Agilent Technologies, Inc. Santa Clara, CA, USA) fitted with a flame ionizing detector and a capillary column (Carbonex ${ }^{\mathrm{TM}}$ Fused silica capillary column $30 \mathrm{~m} \times 0.25 \mathrm{~mm} \times 0.25 \mu \mathrm{m}$ film thickness, Supelco, Bellefonte, USA) as outlined by Erwin et al. [18]. Ammonia-N was determined according to a procedure outlined by Chaney et al. [19].

\section{Total deoxyribonucleic acid extraction (DNA)}

The supernatant and pellet remaining in $50 \mathrm{ml}$ conical tubes after sampling for VFA and ammonia-N analyses were thoroughly mixed to get a representative sample for total DNA extraction. Metagenomic DNA was extracted from $250 \mu \mathrm{l}$ of fermentation fluid by bead beating and purified using a QIAamp ${ }^{\oplus}$ DNA stool mini kit (QIAGEN, Seoul, Korea). In order to ensure higher DNA yield, $1 \mathrm{ml}$ of sample was pipetted into a micro tube using a wide end tip, centrifuged $\left(16000 \times g, 4{ }^{\circ} \mathrm{C}, 5 \mathrm{~min}\right)$ and the supernatant discarded. Another $1 \mathrm{ml}$ of fermentation fluid sample was added to the tube with pellet and centrifuged again $\left(16000 \times g, 4{ }^{\circ} \mathrm{C}, 5\right.$ $\mathrm{min})$. The supernatant was discarded and $400 \mu \mathrm{l}$ of fermentation fluid sample added into the tube with pellet and homogenized. After allowing the mixture to settle for $2 \mathrm{~min}, 250 \mu \mathrm{l}$ of the sample was used in the extraction of DNA. Lysis buffer was added to the sample and the mixture homogenized for 3 min using a BeadBug microtube homogenizer (Benchmark Scientific, Edison, NJ, 
USA). After incubation at $70{ }^{\circ} \mathrm{C}$ for $15 \mathrm{~min}$, with gentle shaking every $5 \mathrm{~min}$, the sample was centrifuged at $4{ }^{\circ} \mathrm{C}$ for $5 \mathrm{~min}$ at 16 $000 \times g$. After transferring the supernatant to a fresh Eppendorf ${ }^{\oplus}$ tube, the process was repeated after adding $300 \mu \mathrm{l}$ of lysis buffer to the lysis tube. In order to precipitate nucleic acids, PPT mix amounting to $10 \%$ of supernatant volume was added to each tube, inverted 4-5 times and placed on ice for $5 \mathrm{~min}$. After centrifuging at $4{ }^{\circ} \mathrm{C}$ for $10 \mathrm{~min}$ at $16000 \times g$, supernatants were transferred to fresh tubes and equal volumes of isopropanol added. After mixing well by pumping, tubes were left on ice for more than 30 min. Samples were then centrifuged $\left(16000 \times g, 4^{\circ} \mathrm{C}, 15 \mathrm{~min}\right)$, the supernatant discarded and $1 \mathrm{ml}$ of $70 \%$ ethanol added. Samples were centrifuged again $\left(16000 \times \mathrm{g}, 4^{\circ} \mathrm{C}, 5 \mathrm{~min}\right)$ and then left to dry for $20 \mathrm{~min}$. The remaining pellet was dissolved in $100 \mu \mathrm{l}$ of TE buffer, and the two aliquots pooled. To remove RNA, $20 \mu \mathrm{l}$ of DNase-free RNase $(1 \mathrm{mg} / \mathrm{ml})$ were added and incubated at $37^{\circ} \mathrm{C}$ for $15 \mathrm{~min}$. After this, DNA was purified using proteinase K and buffers AL, AW1, AW2 and AE of QIAGEN (QIAGEN Inc. Seoul, Korea). The DNA yield was quantified using an Epoch spectrophotometer (BioTek, Winooski, VT, USA).

\section{Real-time PCR primers and assay conditions}

A CFX96 Real-Time System (BioRad, CA, USA) was used to carry out qPCR analyses. PCR primers to amplify target $16 \mathrm{~S}$ rRNA genes for general bacteria and archaea, and 18S rRNA gene for protozoa were chosen form literature. Primers for total bacteria used were Forward: 341f GC 5'-CCTACGGGAGGCAGCAG-3' and Reverse: 534r GC 5' ATTACCGCGGCTGCTGG-3' [20]. Archaea primers were Forward: Met630f 5'-GGATTAGATACCCSGGTAGT-3' and Reverse: Met803r 5'-GTTGARTCCAATTAAACCGC-3' [21]. Protozoa primers were Forward: 316f 5'-GCTTTCGWTGGTAGTGTATT-3' and Reverse: 539r 5'-CTTGCCCTCYAATCGTWCT-3' [22].

Real-time PCR amplification for total bacteria target genes was initiated by a hot start at $94{ }^{\circ} \mathrm{C}$ for 5 min followed by 30 cycles of $80{ }^{\circ} \mathrm{C}$ for $60 \mathrm{~s}, 65^{\circ} \mathrm{C}$ for $60 \mathrm{~s}, 55^{\circ} \mathrm{C}$ for $60 \mathrm{~s}$ and an extension of $72{ }^{\circ} \mathrm{C}$ for $3 \mathrm{~min}$. As for archaea, amplification was initiated by denaturation at $94^{\circ} \mathrm{C}$ for $4 \mathrm{~min}$ followed by 35 cycles of denaturation $\left(94^{\circ} \mathrm{C}\right.$ for $\left.30 \mathrm{~s}\right)$, annealing $\left(52^{\circ} \mathrm{C}\right.$ for $\left.30 \mathrm{~s}\right)$ and extension $\left(72{ }^{\circ} \mathrm{C}\right.$ for $60 \mathrm{~s})$ and then a final extension $\left(72^{\circ} \mathrm{C}\right.$ for $\left.7 \mathrm{~min}\right)$. Protozoa shared similar initial denaturation conditions with archaea, followed by 45 cycles of denaturation $\left(94^{\circ} \mathrm{C}\right.$ for $\left.30 \mathrm{~s}\right)$, annealing $\left(54^{\circ} \mathrm{C}\right.$ for $\left.30 \mathrm{~s}\right)$ and extension $\left(72{ }^{\circ} \mathrm{C}\right.$ for $\left.60 \mathrm{~s}\right)$ and then a final extension $(72$ ${ }^{\circ} \mathrm{C}$ for $\left.6 \mathrm{~min}\right)$. Standards were created from DNA extracted from rumen fluid samples used in this study. Ten-fold series dilutions of the standards were made and used to create standard curves. The starting quantities of target genes for samples were determined from the respective standard curves of the different microbes.

\section{Statistical analyses}

To determine the overall effect of treatments, data generated were analyzed as repeated measures using MIXED procedures of SAS 9.2 [23]. The following model was used;

Where

$$
\mathrm{Y}_{\mathrm{ijk}}=\mu+\tau_{\mathrm{i}}+\beta_{\mathrm{j}}+(\tau \beta)_{\mathrm{ij}}+\pi_{\mathrm{k}}+\epsilon_{\mathrm{ijk}}
$$

$\mathrm{Y}_{\mathrm{ijk}}=$ Response variable

$\mu=$ overall mean common to all observations

$\tau_{i}=$ the ith time effect

$\beta_{\mathrm{j}}=$ the $\mathrm{jth}$ treatment effect

$(\tau \beta)_{\mathrm{ij}}=$ interaction ith time and the jth treatment

$\pi_{\mathrm{k}}=$ random error with mean 0 and variance $\sigma 2$, the variance between vessels within treatment

$\epsilon_{\mathrm{ijk}}=$ random error term

Data on microbial populations were log-transformed first to achieve normality before they were subjected to the same statistical analysis as other data. The effect of treatments at each three-day interval was analyzed by one-way ANOVA. Means were separated using the LSMEANS procedure. A p-value was interpreted as significant when $\mathrm{p} \leq 0.05$ and as tendency when $0.05<\mathrm{p} \leq 0.10$.

\section{Results}

\section{Total gas, $\mathrm{pH}$, methane $\left(\mathrm{CH}_{4}\right)$ and hydrogen $\left(\mathrm{H}_{2}\right)$}

The effect of treatments on rumen fermentation parameters at each sampling period (3,6 and $9 \mathrm{~d})$ are shown in Table 1. Significant overall treatment $\times$ incubation day interactions were observed on $\mathrm{pH}(\mathrm{p}=0.0365)$, total gas $(\mathrm{p}=0.0016), \mathrm{CH}_{4}(\mathrm{p}=0.0011)$ and $\mathrm{H}_{2}(\mathrm{p}=0.0001)$. Carvacrol and thymol increased $(\mathrm{p}<0.0001)$ fermentation culture $\mathrm{pH}$ compared to the control. Garlic oil did not affect $(\mathrm{p}=0.4736) \mathrm{pH}$. The plant-based compounds reduced $(\mathrm{p}<0.0001)$ overall total gas compared to the control, with carvacrol and thymol suppressing $(\mathrm{p}<0.0001)$ total gas more than garlic oil. Statistical analyses at each sampling period revealed differences in total gas between the control and garlic oil to be at day 3 . Whereas garlic oil sustained a total gas output of $\sim 70 \mathrm{ml}$, carvacrol and thymol reduced total gas output from $51.33 \mathrm{ml}$ at day 3 to $39.67 \mathrm{ml}$ at day 9 . Although carvacrol and thymol lowered (p $<0.0001$ ) $\mathrm{CH}_{4}$ on the whole, the $\mathrm{CH}_{4}$ output increased from almost $0 \%$ to $5 \%$ of total gas between days 3 and 9 . Garlic oil on the other hand consistently lowered $\mathrm{CH}_{4}$ to negligible amounts. Treatments influenced $\mathrm{H}_{2}(\mathrm{p}=0.006)$. The greatest amounts of $\mathrm{H}_{2}$ were recorded in carvacrol and thymol, followed by garlic oil, and the least was found in the control. Interesting to note are the trends in the plant-based compounds. Whereas the phenolics resulted in a diminishing $\mathrm{H}_{2}$ output to almost zero by day 9 , garlic oil conversely increased $\mathrm{H}_{2}$ concentration. 


\begin{tabular}{|c|c|c|c|c|c|c|}
\hline \multirow{2}{*}{ Parameter } & \multirow{2}{*}{$\begin{array}{c}\text { Incubation } \\
\text { time }(\mathrm{d})\end{array}$} & \multicolumn{4}{|c|}{ Treatment $^{2}$} & \multirow{2}{*}{$P$ - value } \\
\hline & & Control & Garlic oil & Carvacrol & Thymol & \\
\hline \multirow{3}{*}{$\mathrm{pH}$} & 3 & $6.53 \pm 0.03^{b}$ & $6.58 \pm 0.01^{b}$ & $6.77 \pm 0.01 \mathrm{a}$ & $6.78 \pm 0.02^{\mathrm{a}}$ & $<0.0001$ \\
\hline & 6 & $6.51 \pm 0.01^{b}$ & $6.48 \pm 0.01^{\mathrm{b}}$ & $6.75 \pm 0.03^{\mathrm{a}}$ & $6.71 \pm 0.01^{\mathrm{a}}$ & $<0.0001$ \\
\hline & 9 & $6.54 \pm 0.07^{b}$ & $6.54 \pm 0.02^{b}$ & $6.79 \pm 0.01^{\mathrm{a}}$ & $6.75 \pm 0.01^{\mathrm{a}}$ & $<0.0001$ \\
\hline \multirow{3}{*}{ Total gas (ml) } & 3 & $94.33 \pm 1.53^{\mathrm{a}}$ & $69.00 \pm 3.00^{b}$ & $52.00 \pm 1.00^{c}$ & $51.33 \pm 0.58^{c}$ & $<0.0001$ \\
\hline & 6 & $76.00 \pm 1.00^{\mathrm{a}}$ & $71.33 \pm 3.06^{a}$ & $42.67 \pm 1.15^{b}$ & $42.67 \pm 2.52^{b}$ & $<0.0001$ \\
\hline & 9 & $84.33 \pm 6.66^{\mathrm{a}}$ & $71.67 \pm 7.77^{a}$ & $39.33 \pm 2.08^{b}$ & $39.67 \pm 1.53^{\mathrm{b}}$ & $<0.0001$ \\
\hline \multirow{3}{*}{$\mathrm{H}_{2}(\%)$} & 3 & $0.04 \pm 0.00^{\mathrm{b}}$ & $2.12 \pm 1.59^{b}$ & $12.11 \pm 2.26^{\mathrm{a}}$ & $13.40 \pm 1.06^{\mathrm{a}}$ & $<0.0001$ \\
\hline & 6 & $0.04 \pm 0.00^{c}$ & $4.58 \pm 3.85^{\mathrm{bc}}$ & $9.80 \pm 1.38^{\mathrm{ab}}$ & $10.85 \pm 1.17^{a}$ & 0.0009 \\
\hline & 9 & $0.06 \pm 0.01$ & $7.68 \pm 6.42$ & $2.34 \pm 1.88$ & $4.42 \pm 5.79$ & 0.2624 \\
\hline \multirow{3}{*}{$\mathrm{CH}_{4}(\%)$} & 3 & $10.39 \pm 1.44^{\mathrm{a}}$ & $0.15 \pm 0.02^{b}$ & $0.58 \pm 0.41^{b}$ & $0.04 \pm 0.04^{\mathrm{b}}$ & $<0.0001$ \\
\hline & 6 & $8.15 \pm 0.61^{\mathrm{a}}$ & $0.45 \pm 0.08^{b}$ & $1.27 \pm 1.13^{\mathrm{b}}$ & $0.66 \pm 0.88^{b}$ & $<0.0001$ \\
\hline & 9 & $9.00 \pm 1.14^{\mathrm{a}}$ & $0.18 \pm 0.05^{\mathrm{b}}$ & $3.64 \pm 0.71^{\mathrm{b}}$ & $2.86 \pm 2.45^{\mathrm{b}}$ & 0.0004 \\
\hline \multirow{3}{*}{$\begin{array}{l}\text { Ammonia-N } \\
(\mathrm{mg} / 100 \mathrm{ml})\end{array}$} & 3 & $7.24 \pm 0.78^{\mathrm{a}}$ & $3.00 \pm 0.41^{\mathrm{b}}$ & $1.69 \pm 0.57^{b c}$ & $1.24 \pm 0.47^{\mathfrak{c}}$ & $<0.0001$ \\
\hline & 6 & $6.29 \pm 0.85^{a}$ & $3.91 \pm 0.98^{\mathrm{b}}$ & $0.39 \pm 0.29^{c}$ & $0.49 \pm 0.21^{c}$ & $<0.0001$ \\
\hline & 9 & $7.31 \pm 1.02^{\mathrm{a}}$ & $6.65 \pm 0.27^{\mathrm{a}}$ & $1.03 \pm 0.65^{b}$ & $1.06 \pm 0.34^{\mathrm{b}}$ & $<0.0001$ \\
\hline \multirow{3}{*}{ Acetate (mM) } & 3 & $30.54 \pm 6.07^{a}$ & $28.00 \pm 0.48^{\mathrm{a}}$ & $7.62 \pm 0.98^{b}$ & $9.13 \pm 0.62^{b}$ & $<0.0001$ \\
\hline & 6 & $30.24 \pm 2.10^{\mathrm{a}}$ & $28.28 \pm 4.37^{\mathrm{a}}$ & $13.27 \pm 0.71^{\mathrm{b}}$ & $15.63 \pm 1.46^{\mathrm{b}}$ & $<0.0001$ \\
\hline & 9 & $29.45 \pm 9.72^{\mathrm{ab}}$ & $39.09 \pm 1.42^{\mathrm{a}}$ & $16.91 \pm 0.66^{b c}$ & $13.97 \pm 1.14^{c}$ & 0.0009 \\
\hline \multirow{3}{*}{$\begin{array}{l}\text { Propionate } \\
\text { (mM) }\end{array}$} & 3 & $21.13 \pm 1.78^{\mathrm{a}}$ & $19.13 \pm 1.02^{\mathrm{a}}$ & $3.51 \pm 0.83^{\mathrm{b}}$ & $1.98 \pm 0.47^{b}$ & $<0.0001$ \\
\hline & 6 & $17.52 \pm 4.57^{\mathrm{a}}$ & $19.77 \pm 2.72^{\mathrm{a}}$ & $6.67 \pm 1.61^{b}$ & $3.82 \pm 1.18^{\mathrm{b}}$ & 0.0003 \\
\hline & 9 & $20.04 \pm 5.17^{a}$ & $23.64 \pm 1.50^{\mathrm{a}}$ & $5.36 \pm 2.73^{b}$ & $1.94 \pm 2.34^{\mathrm{b}}$ & $<0.0001$ \\
\hline \multirow{3}{*}{$\begin{array}{l}\text { nButyrate } \\
(\mathrm{mM})\end{array}$} & 3 & $7.28 \pm 0.12^{\mathrm{a}}$ & $6.46 \pm 0.51^{\mathrm{a}}$ & $3.43 \pm 0.48^{b}$ & $4.39 \pm 0.40^{\mathrm{b}}$ & $<0.0001$ \\
\hline & 6 & $10.50 \pm 1.91^{\mathrm{a}}$ & $9.83 \pm 0.45^{\mathrm{a}}$ & $5.06 \pm 0.84^{b}$ & $8.25 \pm 1.08^{\mathrm{a}}$ & 0.0022 \\
\hline & 9 & $13.65 \pm 1.15^{\mathrm{a}}$ & $11.85 \pm 0.52^{\mathrm{a}}$ & $6.51 \pm 0.51^{\mathrm{b}}$ & $7.91 \pm 1.48^{\mathrm{b}}$ & $<0.0001$ \\
\hline \multirow{3}{*}{$\begin{array}{l}\text { nValerate } \\
\quad(\mathrm{mM})\end{array}$} & 3 & $8.91 \pm 0.25^{\mathrm{a}}$ & $5.33 \pm 0.25^{\mathrm{b}}$ & $2.40 \pm 0.33^{c}$ & $1.53 \pm 0.19^{d}$ & $<0.0001$ \\
\hline & 6 & $7.84 \pm 2.49 a$ & $8.97 \pm 0.74^{a}$ & $2.38 \pm 0.47^{b}$ & $1.66 \pm 0.36^{\mathrm{b}}$ & 0.0003 \\
\hline & 9 & $8.05 \pm 3.44^{\mathrm{a}}$ & $7.79 \pm 2.08^{\mathrm{a}}$ & $1.15 \pm 0.40^{\mathrm{b}}$ & $1.43 \pm 1.60^{\mathrm{b}}$ & 0.0055 \\
\hline \multirow{3}{*}{$\begin{array}{l}\text { Total VFA } \\
(\mathbf{m M})\end{array}$} & 3 & $69.85 \pm 7.52 a$ & $59.83 \pm 1.68^{\mathrm{a}}$ & $19.03 \pm 1.10^{\mathrm{b}}$ & $17.63 \pm 0.31^{b}$ & $<0.0001$ \\
\hline & 6 & $67.62 \pm 6.60^{\mathrm{a}}$ & $70.51 \pm 4.21^{\mathrm{a}}$ & $27.68 \pm 2.07^{b}$ & $29.62 \pm 2.64^{b}$ & $<0.0001$ \\
\hline & 9 & $74.52 \pm 15.41^{\mathrm{a}}$ & $83.69 \pm 1.57^{\mathrm{a}}$ & $30.15 \pm 3.15^{b}$ & $26.05 \pm 4.76^{\mathrm{b}}$ & $<0.0001$ \\
\hline \multirow{3}{*}{$\mathbf{A} / \mathbf{P}^{\mathbf{1}}$} & 3 & $1.44 \pm 0.17^{\mathrm{b}}$ & $1.47 \pm 0.08^{\mathrm{b}}$ & $2.29 \pm 0.76^{b}$ & $4.85 \pm 1.48^{\mathrm{a}}$ & 0.0032 \\
\hline & 6 & $1.80 \pm 0.44^{\mathrm{b}}$ & $1.43 \pm 0.03^{b}$ & $2.07 \pm 0.48^{b}$ & $4.34 \pm 1.36^{\mathrm{a}}$ & 0.0058 \\
\hline & 9 & $1.46 \pm 0.16^{\mathrm{b}}$ & $1.66 \pm 0.16^{\mathrm{a}}$ & $3.64 \pm 1.42^{\mathrm{a}}$ & $11.02 \pm 7.17^{\mathrm{a}}$ & 0.0389 \\
\hline
\end{tabular}

${ }^{1} \mathrm{~A} / \mathrm{P}:$ Acetate : Propionate

${ }^{2}$ Treatments were: control (no additive), garlic oil, carvacrol and thymol each at a final concentration of $300 \mathrm{mg} / \mathrm{l}$;

a,b,c,d Significantly different ( $\mathrm{p} \leq 0.05)$. Data presented as Mean $\pm \mathrm{SD} ; n=3$ per treatment

Table 1: Effect of treatments on in vitro rumen fermentation parameters

\section{Ammonia nitrogen (N) and volatile fatty acids (VFAs)}

The addition of carvacrol, thymol and garlic oil resulted in suppressed $(\mathrm{p}<0.0001)$ ammonia-N, with the latter having a lesser effect compared to the phenolics. Whereas carvacrol and thymol maintained a consistent low ammonia- $\mathrm{N}$ concentration, ammonia- $\mathrm{N}$ in garlic oil steadily increased with incubation time until no difference was observed when compared to the control at day 9. Garlic oil did not alter $(p>0.05)$ individual or total VFA with the exception of lowering $(p=0.04)$ butyrate. However, carvacrol and thymol suppressed $(\mathrm{p}<0.0001)$ individual and total VFA. Thymol resulted in a greater $(\mathrm{p}=0.013) \mathrm{A} / \mathrm{P}$ ratio than the rest of the treatments. 


\section{Rumen microbial populations}

The effect of treatments on microbial populations at each sampling period is shown in Table 2. No overall treatment effects $(\mathrm{p}=$ $0.235)$ were observed on total bacteria. On the whole, garlic oil and thymol suppressed $(\mathrm{p}<0.05)$ methanogenic archaea compared to the control but carvacrol did not differ $(\mathrm{p}=0.5046)$ from the control. Significant treatment $\times$ incubation day interactions $(\mathrm{p}=$ $0.0116)$ on methanogens were observed. Although no overall treatment effects $(p=0.2139$ ) were observed on protozoa numbers, the phenolics significantly suppressed protozoa numbers compared to the control and garlic oil at day 3 of fermentation.

\begin{tabular}{|c|c|c|c|c|c|c|}
\hline \multirow{2}{*}{$\begin{array}{l}\text { Rumen microbes (copy } \\
\text { No./ ml, } \log _{10} \text { ) }\end{array}$} & \multirow{2}{*}{$\begin{array}{l}\text { Incubation } \\
\text { time (d) }\end{array}$} & \multicolumn{4}{|c|}{ Treatment } & \multirow{2}{*}{$P$ - value } \\
\hline & & Control & Garlic oil & Carvacrol & Thymol & \\
\hline \multirow{4}{*}{ Total bacteria } & 0 & $9.25 \pm 0.10$ & $9.74 \pm 0.37$ & $9.46 \pm 0.15$ & $9.53 \pm 0.19$ & 0.1553 \\
\hline & 3 & $10.20 \pm 0.24$ & $10.35 \pm 0.34$ & $10.09 \pm 0.39$ & $9.81 \pm 0.31$ & 0.2845 \\
\hline & 6 & $10.17 \pm 0.36$ & $10.37 \pm 0.54$ & $10.39 \pm 0.34$ & $10.02 \pm 0.17$ & 0.6123 \\
\hline & 9 & $10.53 \pm 0.49$ & $10.71 \pm 0.19$ & $10.36 \pm 0.14$ & $10.29 \pm 0.24$ & 0.3646 \\
\hline \multirow{4}{*}{ Methanogenic archaea } & 0 & $4.77 \pm 0.16$ & $4.98 \pm 0.08$ & $5.03 \pm 0.18$ & $4.92 \pm 0.36$ & 0.5314 \\
\hline & 3 & $6.07 \pm 0.21^{\mathrm{a}}$ & $5.40 \pm 0.48^{\mathrm{a}}$ & $5.42 \pm 0.41^{\mathrm{a}}$ & $4.45 \pm 0.13^{b}$ & 0.0026 \\
\hline & 6 & $5.49 \pm 0.11$ & $4.98 \pm 0.11$ & $5.56 \pm 0.53$ & $4.72 \pm 0.79$ & 0.1796 \\
\hline & 9 & $4.95 \pm 0.16$ & $4.71 \pm 0.20$ & $5.16 \pm 0.04$ & $5.18 \pm 0.30$ & 0.0632 \\
\hline \multirow{4}{*}{ Protozoa } & 0 & $4.90 \pm 0.09$ & $5.03 \pm 0.11$ & $4.84 \pm 0.04$ & $4.85 \pm 0.09$ & 0.0809 \\
\hline & 3 & $4.06 \pm 0.15$ & $4.07 \pm 0.10$ & $3.66 \pm 0.17^{b}$ & $3.46 \pm 0.15^{\mathrm{b}}$ & 0.0020 \\
\hline & 6 & $3.33 \pm 0.28$ & $3.92 \pm 0.36$ & $3.97 \pm 0.50$ & $3.96 \pm 0.06$ & 0.1279 \\
\hline & 9 & $2.51 \pm 0.38$ & $1.95 \pm 1.69$ & $1.58 \pm 1.38$ & $2.00 \pm 0.49$ & 0.7957 \\
\hline
\end{tabular}

a,b Significantly different $(\mathrm{p} \leq 0.05)$. Data presented as Mean \pm SD; $n=3$ per treatment; Treatments were: control (no additive), garlic oil, carvacrol and thymol each at a final concentration of $300 \mathrm{mg} / \mathrm{l}$

Table 2: Effect of treatments on microbial counts (copy No./ $\mathrm{ml}$ of fermentation fluid, $\log _{10}$ ) after 3, 6 and 9 days of in vitro fermentation

\section{Discussion}

The observed increase in $\mathrm{pH}$ at the inclusion of carvacrol and thymol is in agreement with earlier studies [3,4,24]. This indicates a negative effect on overall fermentation, a hypothesis supported by suppressed VFA concentrations observed in this study. The suppressed gas production and $\mathrm{CH}_{4}$ in thymol and carvacrol is in agreement with previous studies [4,25]. Garlic oil has also been reported to suppress gas production [26], which is apparent at day 3, but the difference between garlic oil and the control group diminished in subsequent samplings. Observations of garlic oil selectively inhibiting methanogens directly as supported by the accumulation of $\mathrm{H}_{2}$ are consistent with earlier studies [5,26]. The increase in $\mathrm{CH}_{4}$ over time in carvacrol and thymol, combined with a decline in $\mathrm{H}_{2}$ is in response to the multiplication of methanogens. As methanogens increased they used up more $\mathrm{H}_{2}$ even though overall fermentation remained low. This corroborates the proposition by Waghorn et al. [27] that plant compounds can reduce $\mathrm{CH}_{4}$ by suppressing fiber digestion. Thymol, however, as evidenced by lower methanogen numbers, is either more potent than carvacrol at the same concentration or has a broader antimicrobial activity. Carvacrol and thymol also exhibited defaunation qualities in early fermentation, a factor that could have aided in the decrease in $\mathrm{CH}_{4}$ as methanogens are associated with protozoa [28-30]. The suppression of $\mathrm{CH}_{4}$ without affecting overall rumen fermentation by garlic oil indicates selective direct inhibition of methanogens [31]. The observed decline in methanogen abundance in the control group could be associated with a decline in protozoa and the low $\mathrm{pH}$ of the culture contents [32]. Also, slight oxygen $\left(\mathrm{O}_{2}\right)$ contamination during subculture transfers cannot be completely ruled out although measures were taken to maintain an anaerobic environment. Methanogens are highly sensitive to even low $\mathrm{O}_{2}$ concentration exposure [33]. The low protozoa concentrations even in the control group can be explained by observations made by Hungate [34] that it is not easy to achieve protozoa numbers in vitro as those observed in the rumen because of problems in maintaining $\mathrm{pH}$ and also waste removal as in the rumen. Although no specific bacteria species were identified as the ones adapting to carvacrol or thymol in this study, microbial adaptation is the most plausible explanation to the present observations. In a study of the effect of a combination of essential oils on pure cultures of rumen microbes, McIntosh et al. [35] reported that Prevotell bryantii and Prevotell ruminocola adapted to essential oils and managed to grow in higher doses.

Previous researchers have consistently reported a decrease in molar proportions of individual and total VFA concentration at the addition of carvacrol or thymol $[4,24,36]$. The low VFA concentrations are strongly related to the negative influence of carvacrol and thymol on dry matter degradability as reported by Martinez et al. [36]. Carvacrol and thymol possess antibacterial properties and have been found to be effective against both Gram-positive and Gram-negative bacteria [37,38]. Their mode of action involves increasing cell membrane fluidity, leakage of plasma protons and potassium ions, a collapse of the cell membrane, cessation of ATP synthesis and ultimately cell death [39]. Just as was observed in this study, Evans et al. [3] also observed an increase in the A/P ratio in thymol. Contrary to reports by Martinez et al. [36] who used an essential oil from Thymus hyemalis rich in carvacrol, carvacrol in this study did not affect the A/P ratio. 
Essential oils obtained from thyme and oregano together with garlic oil reduced ammonia-N in vitro [25]. Cardozo et al. [40] also reported a decrease in ammonia- $\mathrm{N}$ at the addition of garlic oil. These reductions in ammonia- $\mathrm{N}$ at the inclusion of these plantbased compounds indicate a suppression of the deamination process. Research has reported on phenolics and garlic oil inhibiting the major rumen bacteria involved in deamination [41,42]. Busquet et al. [7], however, found no significant effect of carvacrol on ammonia-N. The discrepancy could be attributed to the low concentration of carvacrol (2.2 mg/l) applied in their study.

\section{Conclusion}

Results obtained in this study suggest that rumen microbes may adapt to carvacrol and thymol but not to garlic oil. The phenolic compounds suppressed overall fermentation, hence low VFA concentrations and $\mathrm{CH}_{4}$ production. However, the antimethanogenic effects of carvacrol and thymol diminished over time, although it could not be determined whether the adaptation would be partial or complete. Whereas garlic oil and thymol suppressed methanogens, carvacrol did not differ from the control suggesting that thymol is more potent at the same concentration or has a broader antibacterial activity than carvacrol. Garlic oil selectively inhibited methanogens. Carvacrol and thymol exhibited defaunation qualities after 3 days of fermentation, but these diminished over time.

\section{Acknowledgement}

This research was supported by The Ministry of Agriculture, Food and Rural Affairs, Korea under the project, 'Research on feed additives for reducing the production of methane by ruminants.

\section{References}

1. Eckard RJ, Grainger C, de Klein CAM (2010) Options for the abatement of methane and nitrous oxide from ruminant production: A review. Livestock Science 130: 47-56.

2. Jouany J (2008) Enteric methane production by ruminants and its control In: Gut efficiency The key ingredient in ruminant, Wageningen Academic Publishers, Netherlands.

3. Evans JD, Martin SA (2000) Effects of thymol on ruminal microorganisms. Curr Microbiol 41: 336-40.

4. Benchaar C, Chaves AV, Fraser GR, Beauchemin KA, McAllister TA (2007) Effects of essential oils and their components on in vitro rumen microbial fermentation. Can J Anim Sci 87: 413-9.

5. Chaves AV, He ML, Yang WZ, Hristov AN, McAllister TA, et al. (2008) Effects of essential oils on proteolytic, deaminative and methanogenic activities of mixed ruminal bacteria. Can J Anim Sci 88: 117-22.

6. Bodas R, Prieto N, García-González R, Andrés S, Giráldez FJ, et al. (2012) Manipulation of rumen fermentation and methane production with plant secondary metabolites. Anim Feed Sci Technol 176: 78-93.

7. Busquet M, Calsamiglia S, Ferret A, Kamel C (2005) Screening for effects of plant extracts and active compounds of plants on dairy cattle rumen microbial fermentation in a continuous culture system. Anim Feed Sci Technol 123: 597-613.

8. Ultee A, Kets EP, Alberda M, Hoekstra FA, Smid EJ (2000) Adaptation of the food-borne pathogen Bacillus cereus to carvacrol. Arch Microbiol 174: 233-8.

9. Benchaar C, Greathead H (2011) Essential oils and opportunities to mitigate enteric methane emissions from ruminants. Anim Feed Sci Technol 166:338-55.

10. Nazzaro F, Fratianni F, De Martino L, Coppola R, De Feo V (2013) Effect of Essential Oils on Pathogenic Bacteria. Pharmaceuticals 6:1451-74.

11. Calsamiglia S, Busquet M, Cardozo PW, Castillejos L, Ferret A (2007) Invited review: Essential oils as modifiers of rumen microbial fermentation. J Dairy Sci 90: 2580-95

12. Kumar S, Choudhury PK, Carro MD, Griffith GW, Dagar SS, et al. (2014) New aspects and strategies for methane mitigation from ruminants. Appl Microbiol Biotechnol 98: 31-44.

13. Patra AK, Saxena J (2009) Dietary phytochemicals as rumen modifiers: a review of the effects on microbial populations. Antonie Van Leeuwenhoek $96: 363-75$.

14. Gascoyne DJ, Theodorou MK (1988) Consecutive batch culture - A novel technique for the in vitro study of mixed microbial populations from the rumen. Anim Feed Sci Technol 21: 183-9.

15. Morgavi DP, Martin C, Boudra H (2013) Fungal secondary metabolites from Monascus spp. reduce rumen methane production in vitro and in vivo. J Anim Sci 91: 848-60.

16. McDougall EI (1948) Studies on ruminant saliva. 1. The composition and output of sheep's saliva. Biochem J 43: 99-109.

17. López S, Valdés C, Newbold CJ, Wallace RJ (1999) Influence of sodium fumarate addition on rumen fermentation in vitro. Br J Nutr 81: 59-64.

18. Erwin ES, Marco GJ, Emery EM (1961) Volatile Fatty Acid Analyses of Blood and Rumen Fluid by Gas Chromatography. J of Dairy Sci 44: $1768-71$.

19. Chaney AL, Marbach EP (1962) Modified reagents for determination of urea and ammonia. Clin Chem 8: 130-2.

20. Muyzer G, de Waal EC, Uitterlinden AG (1993) Profiling of complex microbial populations by denaturing gradient gel electrophoresis analysis of polymerase chain reaction-amplified genes coding for 16S rRNA. Appl Environ Microbiol 59: 695-700.

21. Sundset MA, Edwards JE, Cheng YF, Senosiain RS, Fraile MN, et al. (2009) Molecular diversity of the rumen microbiome of Norwegian reindeer on natural summer pasture. Microb Ecol 57: 335-48.

22. Sylvester JT, Karnati SK, Yu Z, Morrison M, Firkins JL (2004) Development of an assay to quantify rumen ciliate protozoal biomass in cows using real-time PCR. J Nutr 134: 3378-84.

23. SAS Institute (2008) The SAS system for Windows. Release 9.2 Edn, Carry, NC, USA. 
24. Macheboeuf D, Morgavi DP, Papon Y, Mousset J-L, Arturo-Schaan M (2008) Dose-response effects of essential oils on in vitro fermentation activity of the rumen microbial population. Anim Feed Sci Technol 145: 335-50.

25. Azizabadi HJ, Mesgaran MD, Vakili SA, Rezayazdi K, Hashemi M (2011) Effect of various medicinal plant essential oils obtained from semi-arid climate on rumen fermentation characteristics of a high forage diet using in vitro batch culture. Afri J Microbiol Res 5: 4812-9.

26. Busquet M, Calsamiglia S, Ferret A, Carro MD, Kamel C (2005) Effect of garlic oil and four of its compounds on rumen microbial fermentation. J Dairy Sci 88: 4393-404.

27. Waghorn GC, Tavendale MH, Woodfield DR (2002) Methanogenesis from forages fed to sheep. Proceedings of the New Zealand Grassland Association 64: 167-71.

28. Belanche A, de la Fuente G, Newbold CJ (2014) Study of methanogen communities associated with different rumen protozoal populations. FEMS Microbiol Ecol 90: 663-77.

29. Tymensen LD, McAllister TA (2012) Community structure analysis of methanogens associated with rumen protozoa reveals bias in universal archaeal primers. Appl Environ Microbiol 78: 4051-6.

30. Tymensen LD, Beauchemin KA, McAllister TA (2012) Structures of free-living and protozoa-associated methanogen communities in the bovine rumen differ according to comparative analysis of $16 \mathrm{~S}$ rRNA and mcrA genes. Microbiology 158: 1808-17.

31. Busquet M, Calsamiglia S, Ferret A, Cardozo PW, Kamel C (2005) Effects of cinnamaldehyde and garlic oil on rumen microbial fermentation in a dual flow continuous culture. J Dairy Sci 88: 2508-16.

32. Moss AR, Jouany J-P, Newbold J (2000) Methane production by ruminants: its contribution to global warming. Ann Zootech $49: 231-53$.

33. Scott RI, Yarlett N, Hillman K, Williams AG, Lloyd D, et al. (1983) The presence of oxygen in rumen liquor and its effects on methanogenesis. J Appl Bacteriol 55: $143-9$.

34. Hungate RE (1966) The rumen and its microbes, Academic Press, New York and London, USA.

35. McIntosh FM, Williams P, Losa R, Wallace RJ, Beever DA, et al. (2003) Effects of essential oils on ruminal microorganisms and their protein metabolism. Appl Environ Microbiol 69: 5011-4.

36. Martínez S, Madrid J, Hernandez F, Megías MD, Sotomayor JA, et al. (2006) Effect of thyme essential oils (Thymus hyemalis and Thymus zygis) and monensin on in vitro ruminal degradation and volatile fatty acid production. J Agric Food Chem 54: 6598-602.

37. Helander IM, Alakomi H-L, Latva-Kala K, Mattila-Sandholm T, Pol I, et al. (1998) Characterization of the Action of Selected Essential Oil Components on Gram-Negative Bacteria. J Agric Food Chem 46: 3590-5.

38. Calsamiglia S, Busquet M, Cardozo PW, Castillejos L, Ferret A, et al. (2007) The Use of Essential Oils in Ruminants as Modifi ers of Rumen Microbial Fermentation. Penn State Dairy Cattle Nutrition Workshop, Grantville, PA.

39. Ultee A, Bennik MH, Moezelaar R (2002) The phenolic hydroxyl group of carvacrol is essential for action against the food-borne pathogen Bacillus cereus. Appl Environ Microbiol 68: 1561-8.

40. Cardozo PW, Calsamiglia S, Ferret A, Kamel C (2004) Effects of natural plant extracts on ruminal protein degradation and fermentation profiles in continuous culture. J Anim Sci 82: 3230-6.

41. Wallace RJ, McEwan NR, McIntosh FM, Teferedegne B, Newbold CJ (2002) Natural products as manipulators of rumen fermentation. Asian-Aust J Anim Sci 15: $1458-68$.

42. Ferme D, Banjac M, Calsamiglia S, Busquet M, Kamel C, et al. (2004) The effects of plant extracts on microbial community structure in a rumen-simulating continuous-culture system as revealed by molecular profiling. Folia Microbiol 49: 151-5. 